\title{
PERBANDINGAN KINERJA OBLIGASI RITEL INDONESIA DENGAN SUKUK RITEL INDONESIA PERIODE TAHUN 2011-2015
}

\author{
Agus Marimin, Ulul Azmi Mustofa, Anik \\ STIE-AAS Surakarta \\ Email: karjunianik@yahoo.co.id
}

\begin{abstract}
This research is descriptive quantitative research which is conducted in 2015-2016. It aims to test the hypothesis relating to the performance comparison of retail bonds with retail Indonesian sukuk over the period 2011-2015. This study builds on the performance of that proxy in the form of coupon yield value in the Indonesian retail bond investments and returns on investments of retail Indonesian sukuk.

Samples are taken in this study. The collecting method uses the data are obtained from the annual report IDX Indonesia Bond Market Directory. The samples used are as many as 81 data. Data are analyzed by using descriptive test, normality test and different test through SPSS software version 15. The result shows that there is no significant difference between the performance of retail bonds with the performance of retail sukuk.
\end{abstract}

Keywords: Indonesian Retail Bonds and Sukuk Retail Indonesia

\section{PENDAHULUAN}

Investasi telah menjadi salah satu kebutuhan bagi masyarakat Indonesia, investasi yang umum dikenal masyarakat ada 2 jenis yaitu investasi pada sektor riil, seperti properti atau emas dan investasi di sektor keuangan yang diantaranya adalah saham, reksadana, obligasi dan sukuk. Pertumbuhan pasar modal di Indonesia mengalami peningkatan yang pesat, hal ini ditandai dengan semakin ramainya transaksi pada Bursa Efek Indonesia. Transaksi tersebut menunjukkan adanya dampak positif pada peningkatan perekonomian Indonesia.

Salah satu bentuk investasi pada pasar modal syariah adalah berinvestasi pada sekuritas syariah. Sekuritas syariah mencakup saham syariah, obligasi syariah (sukuk), reksadana syariah, dan surat berharga lainnya yang sesuai dengan prinsip syariah. Investasi dengan pemilikan sekuritas syariah dapat dilakukan di pasar modal syariah, baik secara langsung pada saat penawaran perdana, maupun melalui transaksi perdagangan sekunder di bursa.

Perkembangan pasar modal syariah di Indonesia telah mengalami kemajuan, sebagai gambaran dari kemajuan tersebut ialah telah diterbitkannya lima Fatwa Dewan Syariah Nasional Majelis Ulama Indonesia (DSN-MUI) No. 20 Tahun 2002 Tentang Pedoman Pelaksanaan 
Investasi untuk Reksadana Syariah, No. 32 Tahun 2002 Tentang Obligasi Syariah, No. 33 Tahun 2002 Tentang Obligasi Syariah Mudharabah, No. 40 Tahun 2003 Tentang Pasar Modal dan Pedoman Umum, dan No. 41 Tahun 2004 Tentang Obligasi Syariah Ijarah.

Terkait dengan diterbitkannya Fatwa-Fatwa tersebut, serta UndangUndang Nomor 19 tahun 2008 tentang Surat Berharga Syariah Negara (selanjutnya SBSN) dan dilaksanakan oleh Menteri Keuangan. Diterbitkan Undang-Undang SBSN tersebut memberikan harapan di tengah APBN yang selalu deficit untuk bias mendorong tersedianya sumber keuangan alternatif bagi neara guna menarik dana dari investor. Ada yang menarik dari salah satu seri SBSN, yaitu sukuk ritel. Sukuk ritel adalah surat berharga Negara yang diterbitkan berdasarkan prinsip syariah, yang ditujukan kepada investor perorangan. Seri ini telah diterbitkan hingga lima kali, diantaranya seri SR-001, SR-002, SR-003, SR-004, dan SR-005. Selama lima kali seri tersebut diterbitkan, terlihat ada permintaan yang fluktuasi.

Dewan Syariah Nasional (DSN) Majelis Ulama Indonesia (MUI) pada tahun 2002 mengeluarkan Fatwa No.32/DSN-MUI/IX/2002 tentang Obligasi Syariah yang kemudian dikenal dengan istilah sukuk. Sejak itu sukuk mulai tumbuh dan berkembang berdampingan dengan obligasi meskipun dalam perbedaan jumlah yang sangat jauh. Dilihat dari sisi tujuan, fungsi utama sukuk sama halnya dengan obligasi. Sukuk akhirnya memiliki peran penting sebagai salah satu sumber pendanaan perusahaan dan menjadi solusi untuk berinvestasi secara syariah mengingat belum ada instrumen jangka panjang syariah pada masa itu. ${ }^{1}$

Obligasi adalah surat utang yang diterbitkan oleh pemerintah atau perusahaan yang bertujuan untuk mendapatkan dana, dimana pihak penerbit obligasi tersebut akan membayarkan sejumlah bunga atau sering disebut sebagai coupon. ${ }^{2}$ Obligasi (bond) dapat didefinisikan sebagai utang jangka panjang yang akan dibayar kembali pada saat jatuh tempo dengan bunga yang tetap jika ada. Obligasi Ritel Indonesia (ORI) diterbitkan oleh Pemerintah Indonesia sejak Agustus 2006. Definisinya adalah surat berharga milik pemerintah yang diterbitkan oleh Departemen Keuangan. Tujuan penerbitan ORI tersebut adalah memberikan kesempatan kepada individu untuk memiliki surat berharga yang diterbitkan pemerintah. Melalui obligasi ritel, investor perorangan dapat menanamkan dananya dengan nilai yang jauh lebih kecil dibandingkan dengan bila berinvestasi di obligasi biasa.

Sampai dengan tahun 2015 Obligasi ritel dan sukuk ritel terus mengalami perkembangan, hal tersebut dapat dilihat dari data berikut:

\footnotetext{
${ }^{1}$ Fatwa Dewan Syariah Nasional Majelis Ulama Indonesia No. 32/DSD-MUI/IX/2002 Tentang Obligasi Syariah.

2 Zalmi Zubir, Manajemen Potofolio: Penerapannya dalam Investasi Saham. Jakarta: Salemba Empat, 2011), hlm. 72
} 
Tabel 1.1

Data obligasi ritel sampai dengan 2015

\begin{tabular}{|l|l|l|l|l|}
\hline Ori & Kupon & \multicolumn{1}{|c|}{ Masa Penawaran } & $\begin{array}{l}\text { Jangka } \\
\text { Waktu }\end{array}$ & Jatuh Tempo \\
\hline \hline 001 & $12,05 \%$ & 17 Juli - 4 Agustus 2006 & 3 Tahun & 08-08-2009 \\
\hline 002 & $9,28 \%$ & 8 Maret - 23 Maret 2007 & 3 Tahun & 28-03-2010 \\
\hline 003 & $9,40 \%$ & 27 Agustus - 7 September 2007 & 4 Tahun & $12-09-2011$ \\
\hline 004 & $9,50 \%$ & 25 Februari - 6 Maret 2008 & 4 Tahun & $12-03-2012$ \\
\hline 005 & $11,45 \%$ & 19 Agustus - 29 Agustus 2008 & 5 Tahun & $15-09-2013$ \\
\hline 006 & $9,35 \%$ & 24 Juli - 7 Agustus 2009 & 3 Tahun & $15-08-2012$ \\
\hline 007 & $7,95 \%$ & 15 Juli - 30 Juli 2010 & 3 Tahun & $15-08-2013$ \\
\hline 008 & $7,30 \%$ & 7 Oktober - 21 Oktober 2011 & 3 Tahun & $15-10-2014$ \\
\hline 009 & $6,25 \%$ & 21 September - 5 Oktober 2012 & 3 Tahun & $15-10-2015$ \\
\hline 010 & $8,50 \%$ & 20 September - 4 Oktober 2013 & 3 Tahun & $15-10-2016$ \\
\hline 011 & $8,50 \%$ & 1 Oktober - 16 Oktober 2015 & 3 Tahun & $16-09-2017$ \\
\hline
\end{tabular}

Sumber: $\underline{w w w . p u s a t i s . c o m}$

Tabel 1.2

Data sukuk ritel sampai dengan 2015

\begin{tabular}{|c|c|c|}
\hline Sukri & Imbal Hasil & Waktu \\
\hline \hline Sr 001 & $12 \%$ & 25 Feb 2009-25 Feb 2012 \\
\hline Sr 002 & $8,70 \%$ & 10 Feb 2010-10 Feb 2013 \\
\hline Sr 003 & $8,15 \%$ & 23 Feb 2011-23 Feb 2014 \\
\hline Sr 004 & $6,25 \%$ & 21 Maret 2012-21 Sept 2015 \\
\hline Sr 005 & $6 \%$ & 27 Feb 2013-27 Feb 2016 \\
\hline Sr 006 & $8,75 \%$ & 5 Maret 2014-5 Maret 2017 \\
\hline Sr 007 & $8,75 \%$ & 11 Maret 2015-11 Maret 2018 \\
\hline
\end{tabular}

Sumber: www.pusatis.com

Dari tabel diatas dapat dijelaskan bahwa obligasi ritel dan sukuk ritel pengalami perkembangan dari tahun ke tahun. Tingkat kupon dan imbal hasil yang ditawarkan fluktuatif. Terlihat bahwa pada obligasi ritel, kupon yang diberikan pada saat penerbitan pertama sukuk ritel seri SR001 tahun 2006 sebesar $12,05 \%$, dan pada obligasi ritel seri ORI011 tahun 2015 memberikan kupon sebesar 8,50\%. Begitu pula dengan sukuk ritel pada tahun pertama penerbitan suku 
ritel seri SR001 tahun 2009 memberikan imbal hasil sebesar $12 \%$ dan terakhir pada tahun 2015 memberikan imbal hasil sebesar $8,75 \%$.

Dilihat dari data yang diterbitkan oleh Direktorat Jenderal Pengelolaan Pembiayaan Dan Risiko serta Direktorat Jenderal Pengelolaan Utang bahwa pertumbuhan kupon obligasi ritel dan imbal hasil sukuk ritel dari tahun ke tahun cukup stabil dan memberikan keuntungan yang menarik, namun hal tersebut belum dapat menarik minat investor dalam negeri untuk menginvestasikan dananya dalam obligasi pemerintah. Selanjutnya adalah apabila dilihat dari tipenya pemerintah menerbitkan dua tipe obligasi yang berbeda yaitu obligasi ritel Indonesia dan sukuk ritel Indonesia dengan karakter yang berbeda, namun sama-sama dikelola oleh pemerintah. Kurangnya informasi dan sosialisasi terkait sukuk ritel membuat investor bingung dalam menilai kinerja investasi. Sehingga dibutuhkan suatu perbandingan antara keuntungan dan risiko pada obligasi ritel dan sukuk ritel, dengan demikian dapat dilihat kinerja keduanya. Dari latar belakang masalah tersebut maka rumusan masalah dalam penelitian ini adalah Apakah terdapat perbedaan kinerja obligasi ritel dengan kinerja sukuk ritel?

\section{OBLIGASI}

Obligasi adalah surat utang yang diterbitkan oleh pemerintah atau perusahaan yang bertujuan untuk mendapatkan dana, dimana pihak penerbit obligasi tersebut akan membayarkan sejumlah bunga atau sering disebut sebagai coupon. ${ }^{3}$ Obligasi atau bond adalah surat utang jangka panjang yang dikeluarkan oleh peminjam, dengan kewajiban untuk membayar kepada bond holder (pemegang obligasi) sejumlah bunga tetap yang telah ditetapkan sebelumnya. ${ }^{4}$ Obligasi (bond) dapat didefinisikan sebagai utang jangka panjang yang akan dibayar kembali pada saat jatuh tempo dengan bunga yang tetap jika ada. Dari definisi ini dapat diketahui bahwa obligasi adalah suatu utang atau kewajiban jangka panjang (bond), sedangkan utang jangka pendek disebut dengan bill.

obligasi adalah suatu pernyataan utang dari penerbt obligasi kepada pemegang obligasi dan janji untuk membayar kembali pokok utang beserta kupon bunganya kelak pada saat tanggal jatuh tempo pembayaran. Ketentuan lain dapat juga dicantumkan dalam obligasi tersebut misalnya, identitas pemegang obligasi, pembatasan-pembatasan atas tindakan hukum yang dilakukan oleh penerbit. $^{5}$

Menurut pasal 1 butir 34 Keputusan Menteri Keuangan Nomor 1548/KMK.013/1990 sebagaimana telah diubah dengan Keputusan Menteri Keuangan nomor 1190/KMK/010.1991, obligasi adalah bukti utang dari emiten yang mengandung janji pembayaran bunga atau janji lainnya serta pelunasan pokok pinjaman yang dilakukan pada

3 Zalmi Zubir, Manajemen Potofolio: Penerapannya dalam Investasi Saham. Jakarta: Salemba Empat, 2011), hlm. 76

4 Sutedi, Aspek Hukum Obligasi Dan

Sukuk, (Jakarta:Sinar Grafika, 2009), hlm. 1

${ }^{5}$ Sutedi, Aspek Hukum Obligasi Dan Sukuk, (Jakarta: Sinar Grafika, 2009), hlm. 1 
tanggal jatuh tempo, sekurang-kurangnya 3 (tiga) tahun setelah emisi. ${ }^{6}$ Dengan demikian, secara umum pada hakikatnya obligasi adalah surat tagihan utang atas beban tanggungan pihak yang menerbitkan atau mengeluarkan obligasi.

Jenis-jenis obligasi dapat dikelompokan berdasarkan pada ${ }^{7}$ :

1) Berdasarkan Penerbitannya

Terdapat beberapa macam obligasi ditinjau dari penerbitnya, di antaranya yaitu obligasi pemerintah (government bond), municipal bond, dan obligasi perusahaan (corporate bond $)^{8}$.
a) Government Bond
b) Municipal Bond
c) Obligasi Perusahaan

2) Berdasarkan Suku Bunga

Suku bunga obligasi dapat dijadikan salah satu pertimbangan utama investor obligasi dalam melakukan transaksi. Macam-macam obligasi berdasarkan suku bunganya yaitu :
a) Floating Rate Bond,
b) Fixed Rate Bond,
c) Mixed Rate Bond,
d) Zero Coupon Bond,

3) Berdasarkan Kepemilikannya

Sebagai produk investasi yang sangat berharga sebuah obligasi mempunyai status kepemilikan yang sangat fleksibel yaitu :

\footnotetext{
${ }^{6}$ Sutedi, Aspek Hukum Obligasi Dan Sukuk, (Jakarta:Sinar Grafika, 2009), hlm. 2

7 Bambang Susilo, Pasar Modal: Mekanisme Perdagangan Saham, Analisis Sekuritas, dan Strategi Investasi di Bursa Efek Indonesia (BEI), (Yogyakarta: UPP STIM YKPN 2009)

8 Jogiyanto, Teori Portopolio Dan Analisis Investasi, (Yogyakarta : BPFE, 2014), hlm. 214.
}

a) Obligasi terdaftar (Register Bond),

b) Atas unjuk (Bearer Bond),

4) Berdasarkan Jaminan

Obligasi berdasarkan jaminan pada umumnya lebih diminati investor karena mempunya unsur jaminan sebagai syarat agar investor mesara aman dalam berinvestasi obligasi. Macam-macam obligasi berdasarkan jaminan yaitu:

a) Obligasi dijamin garansi (Guaranted Bond),

b) Obligasi dijamin properti (Mortgage Bond),

c) Obligasi dijamin surat berharga (Collateral Bond),

d) Obligasi dijamin dengan peralatan (Equipment Bond),

e) Obligasi tanpa jaminan (Debenture Bond),

5) Berdasarkan pelunasan

Berdasarkan pelunasannya dapat dibedakan menjadi berikut :
a) Serial bond,
b) Collable bond,
c) Putabel bond,

\section{OBLIGASI RITEL INDONESIA}

Obligasi Negara Ritel merupakan bagian dari Obligasi Negara. Sementara Obligasi Negara merupakan bagian dari Surat Utang Negara. Dalam UndangUndang No. 24 Tahun 2002 tentang Surat Utang Negara disebutkan bahwa Surat Utang Negara ialah surat berharga yang berupa surat pengakuan utang dalam mata uang rupiah maupun valuta asing yang dijamin pembayaran bunga dan pokoknya oleh Negara Republik Indonesia, sesuai dengan masa berlakunya. Obligasi Negara ialah surat utang yang diterbitkan 
Pemerintah yang memiliki jangka waktu lebih dari 12 bulan dengan kupon dan atau pembayaran bunga secara diskonto. ${ }^{9}$

$$
\text { Obligasi Negara Ritel adalah }
$$

Obligasi Negara yang diterbitkan oleh Pemerintah Indonesia untuk dijual kepada individu atau orang perseorangan Warga Negara Indonesia melalui Agen Penjual. Agen Penjual yang dimaksud ialah bank dan atau perusahaan efek yang ditunjuk oleh Menteri Keuangan untuk melaksanakan penjualan Obligasi Negara Ritel. Dasar Hukum dalam menerbitkan ORI ini terdapat dasar hukum yang menyertainya, yaitu sebagai berikut:

a) Undang-Undang No. 24 Tahun 2002 tentang Surat Utang Negara

b) Peraturan Menteri Keuangan No. 36/PMK.06/2006 tentang Penjualan Obligasi Negara Ritel di Pasar Perdana

c) Peraturan Menteri Keuangan No. 10/PMK.08/2007 tentang Perubahan Atas Peraturan Menteri Keuangan No. 36/PMK.06/2006 tentang Penjualan Obligasi Negara Ritel di Pasar Perdana

\section{SUKUK}

Sukuk adalah suatu surat berharga jangka panjang berdasarkan prinsip syariah yang dikeluarkan oleh emiten kepada investor (pemegang obligasi) yang mewajibkan emoiten untuk membayar pendapatan kepada investor berupa bagi

${ }^{9}$ www.pusatis.com diakses pada 2 Februari 2016 hasil/marjin/fee serta membayar kembali dana investasi pada saat jatuh tempo. ${ }^{10}$

Sukuk memiliki beberapa karakteristik, yaitu pertama, sukuk menekankan pendapatan investasi bukan berdasarkan tingkat bunga (kupon) yang telah ditentukan sebelumnya. Tingkat pendapatan oblgasi syariah berdasarkan pada tingkat rasio bagi hasil (nisbah) yang besarannya telah disepakati oleh pihak emiten dan investor. Kedua, dalam sistem pengawasannya selain diawasi oleh pihak wali amanat maka mekanisme sukuk juga diawasi oleh dewan pengawas syariah (di bawah majelis ulama Indonesia) sejak dari penerbitan obligasi sampai akhir dari masa penerbitan obligasi tersebut. Ketiga, jenis industri yang dikelola oleh emiten serta hasil pendapatan perusahaan penerbit sukuk harus terhindar dari unsur non halal. $^{11}$

Instrument-insrtumen syariah yang dikeluarkan oleh badan usaha atau lembaga keuangan selalu diawali dengan adanya Fatwa dari Dewan Syariah Nasional (DSN) yang menjadi dasar hukum keabsahan suatu produk. Hanya saja yang menjadi pertanyaan adalah apakah Fatwa DSN tersebut dapat dijadikan sebagai sebuah dasar hukum yang mengikat, mengingat Fatwa DSN tidak termasuk dalam Tata Urutan Perundang-Undangan Republik Indonesia sebagaimana diatur dalam UndangUndang Nomor 10 Tahun 2004 Tentang Pembentukan Peraturan Perundang-

\footnotetext{
${ }^{10}$ Lihat Dalam Ketentuan Umum Fatwa Dewan Syari'ah Nasional Nomor 59/DSNMUI/V/2007 Tentang Obligasi Syari'ah

${ }^{11}$ Sutedi, Aspek Hukum Obligasi Dan Sukuk, (Jakarta: Sinar Grafika, 2009), hlm. 127
} 
Undangan. Dalam Pasal 7 Ayat (1) Undang-Undang Tahun 2004 ditegaskan bhwa jenis dan hirarki peraturan perundang-undangan adalah sebagai berikut:

1) Undang-undang dasar Negara Republik Indonesia tahun 1945

2) Undang-undang/peraturan pemerintah pengganti undang-undang

3) Peraturan pemerintah

4) Peraturan presiden

5) Peraturan daerah

\section{SUKUK RITEL}

Surat Berharga Syariah Negara Ritel (Sukuk Ritel) adalah surat berharga negara yang diterbitkan berdasarkan prinsip syariah sebagai bukti atas bagian penyertaan terhadap Aset Surat Berharga Syariah Negara, yang dijual kepada individu atau perseorangan Warga Negara Indonesia melalui Agen Penjual, dengan volume minimum yang telah ditentukan. ${ }^{12}$

Underlying asset adalah asset yang dijadikan sebagai objek atau dasar transaksi dalam kaitannya dengan penerbitan sukuk. Tanpa adanya underlying asset surat berharga ynag diterbitkan akan sama dengan sifatnya sebagai instrumen utang. Sesuai dengan undang-undang tentang SBSN Underlying asset pada SBSN berupa objek pembiayaan SBSN atau barang milik Negara (BMN) yang bernilai ekonomis.

Adapun rumusan hipotesis dalam penelitian ini dinyatakan sebagai berikut: $\mathrm{H}_{0}$ : tidak ada perbedaan kinerja antara obligasi ritel dan sukuk ritel

\footnotetext{
${ }^{12}$ Direktorat Pembiayaan Syariah Direktorat Jenderal Pengelolaan Utang, Brosur Sukuk Negara, Jakarta: 2013.
}

$\mathrm{H}_{1}$ : Ada perbedaan kinerja antara obligasi ritel dan sukuk ritel

\section{METODOLOGI PENELITIAN Jenis dan Sifat Data}

Jenis data yang digunakan dalam penelitian ini adalah data sekunder yang diambil dari publikasi Indonesian Bond Marker Directory 2011-2014, Bursa Efek Indonesia, dan IDX. Penelitian ini bersifat komparatif, yaitu penelitian yang membandingkan tingkat kinerja obligasi ritel dengan sukuk ritel yang dilihat dari yield dan risk yang kemudian dianalisis dengan analisis statistik menggunakan Microsoft Excel.

\section{Populasi dan Simpel data}

Populasi pada penelitian ini adalah obligasi konvensional dan obligasi syariah (sukuk) yang diterbitkan dari tahun 2010 sampai dengan 2014. sampel yang digunakan penulis dalam penelitian ini adalah obligasi ritel mulai dari ORI seri SR002 sampai dengan seri SR 010 dan sukuk ritel mulai dari seri 002 sampai dengan seri 005 tahun 2011 sampai dengan tahun 2014.

\section{Teknik Analisis Data}

\section{Diskriptif Statistik}

Metode analisis yang digunakan dalam penelitian ini adalah analisis deskriptif kuantitatif, yang digunakan untuk mengukur dan menganalisis ukuran kinerja surat berharga yang terdiri dari obligasi ritel dan sukuk ritel. Langkah-langkah dalam menganalisis data yang diperoleh dari Indonesia Bond Market Directory IDX untuk mengukur kinerja surat berharga 
tersebut. Dalam deskriptif statistik akan dilihat hasil minimum, maximum dan rata-rata (mean). Dari angka-angka pada minimum, maximum dan rata-rata (mean) tersebut akan dijelaskan arti dari output yang dihasilkan dalam olah data.

2. Uji Normalitas

Pengujian normalitas dengan spss 15 for windows dengan menggunakan uji skewness dan kurtosis dengan pengambilan keputusan Asymp. Sig $>0,005$ maka data berdistribusi normal dan jika Asymp. Sig< 0,005 maka data berdistribusi tidak normal.

3. Uji Independent Simple T-Test

Untuk menguji hipotesis digunakan uji independent sample $t$ test. Pengujian hipotesis dengan menggunakan uji t dengan langkahlangkah sebagai berikut:

a. Merumuskan hipotesis

$\mathrm{H}_{0}$ : tidak ada perbedaan kinerja

Obligasi Ritel dan Sukuk Ritel

$\mathrm{H}_{1}$ : ada perbedaan kinerja Obligasi Ritel dan Sukuk Ritel

b. Menentukan tingkat signifikan dimana $a=0,05$ atau $5 \%$

c. Menghitung $t$ hitung dengan menggunakan SPSS 15 for windows

d. Kesimpulan untuk menolak atau menerima $\mathrm{H}_{0}$, berdasarkan bentuk perumusan hipotesisnya, yaitu:

1) Jika probabilitas (sig) t $>0,05$ maka $\mathrm{H}_{0}$ diterima jadi variance sama.

2) Jika probabilitas (sig) $\mathrm{t}<0,05$ maka $\mathrm{H}_{0}$ ditolak jadi variance berbeda.

\section{HASIL DAN PEMBAHASAN}

Deskripsi Statistik Obligasi Ritel dan Sukuk Ritel

\begin{tabular}{|lcc|}
\hline & Obligasi ritel & Sukuk ritel \\
\hline $\mathrm{N}$ & 47 & 34 \\
Minimum & 3.05 & 4.32 \\
Maximum & 8.50 & 8.59 \\
Mean & 6.1831 & 6.4371 \\
Std. deviation & 1.28036 & 1.20364 \\
\hline
\end{tabular}

Sumber: data diolah, 2016

Berdasarkan hasil deskripsi statistik menunjukan bahwa jumlah data Obligasi Ritel Indonesia sebanyak 47 data dan jumlah data pada Sukuk Ritel Indonesia adalah sebanyak sebanyak 34 data. Adapun jumlah data keseluruhan adalah 81 data.
Nilai minimum pada Obligasi Ritel adalah sebesar 3,05 yang artinya bahwa kupon terendah dari investasi obligasi ritel adalah sebesar $3,05 \%$ dan nilai minimum dari sukuk ritel adalah sebesar 4,32 yang artinya bahwa imbal hasil terendah dari investasi sukuk ritel 
adalah sebesar 4,32\% serta dapat disimpulkan bahwa nilai minimum dari sukuk ritel lebih tinggi dibandingkan nilai minimum obligasi ritel.

Nilai maximum dari Obligasi Ritel adalah sebesar 8,50 yang artinya bahwa kupon tertinggi dari investasi obligasi ritel adalah senilai $8,5 \%$, kupon tersebut lebih tinggi dari pada suku bunga deposito. Nilai maksimum dari sukuk ritel adalah sebesar 8,59 yang artinya bahwa imbal hasil tertinggi dari investasi sukuk ritel adalah sebesar 8,59\%. Hal ini berarti imbal hasil tertinggi sukuk ritel lebih besar dari pada kupon tertinggi obligasi ritel dan berarti pula bahwa imbal hasil investasi sukuk ritel lebih menguntungkan dari pada suku bunga deposito. Nilai rata-rata (mean) pada Obligasi Ritel Indonesia adalah senilai 6.1831 yang artinya bahwa kupon rata-rata dari investasi obligasi ritel adalah senilai $6,1831 \%$ dan nilai rata-rata (mean) pada sukuk ritel adalah sebanyak 6.4371 yang artinya bahwa rata-rata imbal hasil dari investasi sukuk ritel adalah senilai $6,4371 \%$.

Uji beda uji independent sample t-test

\begin{tabular}{|c|c|c|c|c|c|c|c|c|c|c|}
\hline & \multirow{3}{*}{\multicolumn{2}{|c|}{$\begin{array}{l}\text { Levene's } \\
\text { Test for } \\
\text { Equality of } \\
\text { Variances } \\
\\
\text { F } \\
\end{array}$}} & \multirow[b]{3}{*}{$\mathrm{T}$} & \multirow[b]{3}{*}{ Df } & \multicolumn{3}{|c|}{ t-test for Equality of Means } & \multirow{2}{*}{\multicolumn{2}{|c|}{$\begin{array}{c}95 \% \text { Confidence } \\
\text { Interval of the } \\
\text { Difference }\end{array}$}} \\
\hline & & & & & & \multirow{2}{*}{$\begin{array}{l}\text { Sig. } \\
(2- \\
\text { tailed) }\end{array}$} & \multirow{2}{*}{$\begin{array}{c}\text { Mean } \\
\text { Difference }\end{array}$} & \multirow{2}{*}{$\begin{array}{l}\text { Std. Error } \\
\text { Difference }\end{array}$} & & \\
\hline & & & & & & & & & Upper & Lower \\
\hline$\overline{\text { Yield }}$ & $\begin{array}{l}\text { Equal } \\
\text { variances } \\
\text { assumed } \\
\text { Equal } \\
\text { variances } \\
\text { not } \\
\text { assumed }\end{array}$ & .000 & .989 & .912 & 73.707 & .365 & $\begin{array}{r}.25396038 \\
80 \\
\\
.25396038 \\
80\end{array}$ & $\begin{array}{r}.28117490 \\
23\end{array}$ & $\begin{array}{r}- \\
.3057 \\
04255 \\
3 \\
- \\
.3007 \\
38784 \\
1\end{array}$ & $\begin{array}{r}.813625 \\
0313 \\
\\
.808659 \\
5601\end{array}$ \\
\hline
\end{tabular}

Sumber: data diolah, 2016

Pada hasil analisis diketahui t hitung sebesar 0.903 dengan signifikansi sebesar 0.989 atau lebih dari 0.05 . Hasil analisis ini menunjukkan bahwa tidak ada perbedaan yang signifikan antara kinerja baik yield Obligasi Ritel maupun yield Sukuk Ritel.
Kinerja obligasi ritel dan sukuk ritel dilihat dari yield (kupon pada obligasi ritel dan imbal hasil pada sukuk ritel) menunjukan bahwa tidak terdapat perbadaan yang signifikan antara kinerja obligasi ritel dengan kinerja sukuk ritel. Dari hasil tabel uji independent sample ttest dapat dilihat bahwa nilai signifikan 
adalah 0,989 . Hal ini berarti berarti bahwa nilai signifikan $0,989>0,05$ yang berarti H0 diterima. Oleh karena itu, tidak terdapat perbedaan yang signifikan antara kinerja obligasi ritel dan sukuk ritel.

Diatas telah dijelaskan karakteristik obligasi ritel dan sukuk ritel, keduanya memiliki banyak perbedaan. Namun dalam penelitian ini hasil yang diperoleh dari olah data menyebutkan bahwa tidak terdapat perbedaan kinerja yang signifikan antara obligasi ritel dan sukuk ritel.

\section{KESIMPULAN}

Berdasarkan hasil analisis dan pembahasan, maka dapat disimpulkan bahwa kinerja obligasi ritel dan sukuk ritel yang diukur dari yield masing-masing menunjukan bahwa tidak ada perbadaan kinerja antara keduanya. Dari hasil uji independent sample t-test, hasil tabel statistik menunjukan bahwa nilai signifikan adalah 0,989. Hal ini berarti berarti bahwa nilai signifikan 0,989>0,05 yang berarti $\mathrm{H}_{0}$ diterima. Oleh karena itu, tidak terdapat perbedaan yang signifikan antara kinerja obligasi ritel dan sukuk ritel.

\section{DAFTAR PUSTAKA}

Fatwa Dewan Syari'ah Nasional Nomor 69/DSN-MUI/VI/2008 tentang

Surat Berharga Syariah Negara.

Jogiyanto, Hartono, 2014, Teori Portopolio Dan Analisis Investasi, Yogyakarta: BPFE-Yogyakarta.
2013, Teori Portofolio dan Analisis Investasi, Yogyakarta: BPFE.

Nazaruddin Abdul Wahid, 2010, Sukuk Memahami Dan Membedah Obligasi Pada Perbankan Syariah, Yogyakarta: Ar-Ruzz Media.

Susilo, Bambang, 2009, Pasar Modal: Mekanisme Perdagangan Saham, Analisis Sekuritas, dan Strategi Investasi di Bursa Efek Indonesia (BEI). Yogyakarta: UPP STIM YKPN.

Sutedi, Adrian, 2009, Aspek Hukum Obligasi Dan Sukuk, Jakarta:Sinar Grafika.

Zubir, Zalmi. 2011. Manajemen Potofolio: Penerapannya dalam Investasi Saham. Jakarta: Salemba Empat. 